DOI: $10.35218 /$ armca.2021.1.14

\title{
About angels
}

\section{Zamfira Bîrzu*}

\begin{abstract}
This work reveals the definition of «angel», a generic classification of angel hierarchies, their main characteristics, a short history about them according to Bible stories and also a history of their representations in iconography. There are also problematised opposite moral aspects, such as: good and bad, spirituality and sin, immortality and ephemerality, sacred and profane, heaven and earth. This theme is analysed from a multiple perspective, such as from a religious, but also from a philosophical and artistic point of view. In the last pages of the article there are 2 paintings entitled «Seraphim» and «Angel» which are visual representations of these heavenly creatures.
\end{abstract}

Keywords: Angel, Seraphim, Cherubim, Wings, Christianity, Sin.

Angels have been present in the culture of mankind sinceits inception. Conceived in different ways by those who watched them or interacted with them, angels proved to be spiritual beings superior to people, but favorable to them, for the most part in their interactions.

Jewish Old Testament theology based on God's divine revelation to the biblical Jewish people, was able to learn the first real things about angels.

Angels have been present in Old Testament stories on various occasions in which they helped people at God's command, in order to create a page out of the sacred history regarding waiting for the Jesus Christ's second coming.

After Jesus's second coming, Eastern Christian theology had enough time to systematize the doctrine of angels and to present it to the world in a complex way. From ancient theologians we know almost everything that can be known up to this time about angels.

We thus know that the name "angel" means "messenger" which derives from the Greek word anghelos, which has this meaning. In the Old Testament, the word for angels was mal'ak, sometimes called mal'ak elohim which means"God's messengers."

Their name also shows us the role they play in the world: that of transmitting God's will to people.

\footnotetext{
*Associate Professor, PhD. George Enescu National University of Arts Iași, Faculty of Visual Arts and Design.
} 
The saint who systematized the knowledge about angels was Saint Dionysius the Areopagite who stated that there are nine groups of angels, organised in triads, depending on their proximity to God or people.

Thus, Saint Dionysius the Areopagite teaches us that there are three groups close to the throne of God. These Choirs of Angels (Triads) are:

- Thrones;

- Seraphim;

- Cherubim.

A middle intermediate Triad, between the throne of God and people, is made up of the following groups:

- Dominios or Lordships;

- Virtues or Strongholds;

- Powers or Authorities.

The closest human triad consists of:

- Principalities or Rulers;

- Archangels;

- Angels.

The nine angelic triads fill, if we will, the ontological void between divine omnipotence and the perishability of this world in which we are all living, of the created and perishing universe.

These extraordinary beings form an ontological scale from earth to heaven, a communication channel between God and his created world, through which God's will is transmitted to people on one hand and on the other hand, prayers and people's desires for the divine throne are transmitted.

The name Seraphim means "those who burn," making reference of course to love for God.

Cherubim means "those who bless," and the thrones are those upon whom God rests, transmitting His commandments to the following triads.

Virtues or Strongholds are the ones who organize the other subordinated traids; Masters (also called Virtues) are those through whom miracles are performed; Powers or Authorities are those that prevent the powers of evil from harming the universe and humanity.

Principalities or Rulers are angels who protect people and administer this world, taking care of it; Archangels are the heads of angels; angels themselves are the ones who take care of people and protect them.

We know about angels that are spiritual, intangible beings with an intuitive knowledge that helps them understand things deeper and faster than the human mind, which has a great ability for mobility and action.

Like any created thing, angels have a beginning, but they don't have an end unlike the rest of the created universe, apart from human being. Everything created by God, except for angels and people, lives and then disappears. Angels and people are not eternal like God, in the sense that they are eternal, always having a beginning, but once they exist, they are alive. 
The knowledge process which cannot be known is considered to be a personal endeavor that is incomplete and imperfect, according to Dionysius Peudo-Areopagite's writings. There are Angels who control natural phenomena, angels of fire, wind and darkness, there are master angels of frost, snow, water, etc. In Egyptian mythology, Archangel Michael took on god Nile's role, becoming responsible for dew and rain. According to Christianity, angels are the masters and guardians of their constituent elements, like: water, air, and fire.

The representation of angels developed during the Byzantine period. After the iconoclastic period which was a manifestation of people's insecurity about their own Universe of thought, there were two opposing conceptions regarding knowledge, symbolic and literary approach, in art and worship. For some theologians, intellectual devotion and material representations were mutually exclusive. There were also times when the worship of angels was excessive. The altar at Chonae, which was one of the main centers of angel worship, is still preserved today. There have been representations of angels since the early Christianity based on the descriptions provided by the Holy Bible. Christian artists have developed an iconography of angels depicting their appearances on earth, most often by representing their wings to suggest their symbolic character. The representation of the transcendent, the ineffable and illusory nature, their appearances described in the Holy Bible show us that the icons of angels symbolise a spiritual reality that cannot be fully known, so the representations of angels are symbolic in a definite way. Angels cannot be represented as Christ and Saints. They left no miraculously printed images or relics. Their timeless being has no recorded earthly face. Angels are formless, disembodied and immaterial. Therefore, the relationship between icon or representation and the prototype is problematic. The tension between the material representation and their immaterial nature is an attractive quality. This tension is the defining feature of the angels' representations and distinguishes their images from other representations.

In Christian art, the symbol of angels is represented in well known paintings, with the appearance of winged young people (generalized anonymous images). Cherubim and Seraphim can be recognized and distinguished from each other by their several wings and eyes representation of the image described in Holy Scripture. Anthropomorphization has become an iconic constant element, but there are other types of representations: cloud pillar and fire pillar. These elements are described in the book called "Exodus" which describes the Angel's guidance of Israelites through wilderness. Pillar and cloud are symbolic aspects of multiform divine beings, their changing appearance requiring special processes of interpretation. In Bible, angels are sometimes described as human, according to their appearance, and having all the metaphysical qualities of angels. Painters, mosaicists, sculptors and artists gave them a human appearance. The earliest 
depiction of a human-shaped angel preserved since the $3^{\text {rd }}$ century in an icon of the Annunciation in the catacomb of Priscilla in Rome.

The wings of these anthropomorphized representations offered the possibility to suggest the supernatural attributes characteristic of angels. The winged form has become the iconic sign of countless and unseen beings, who mediate between heaven and earth and symbolize the metaphysical dimension. Glenn Peers mentions that there is an iconographic parallel between winged pagan beings and Christian angels. Here is clearly noticed the inspiration in the Pre-Christian representations of some deities. Pagan imagery is obvious, pagan art was the first source of inspiration for later representations of angels.

The figure with six wings and four faces stands on wheels of fire. These descriptions refer to Ezekiel. Wings have always been used as the main means of suggesting the symbolic nature of angel representations. Color and clouds were used to symbolise the fire and wind the angels were made of. Example of representations: the red angel suggests fire and light; the blue angel suggests the dark nature of the fallen angel.

The celestial powers are, by their nature, spirit and breath of immaterial wind or fire. Wings signal transcendence and immateriality, spiritual nature as well as supernatural speed. PseudoDionysius the Areopagite researched in his work called "The Heavenly Hierarchy", various passages of Scripture and made a detailed analysis of the incarnate creatures of God and their non-figurative, symbolic representations of angels.

"The image of those with no face and the appearance of those with no appearance" "The ungodly servants of God." Angels, souls, demons are "corporeal", but inaccessible to human view (with few exceptions). Their body has a different nature, closer to energy (between matter and energy). A raw energy that can take different forms and can be in different places. Unlike God, who is subtle energy and is at the same time everywhere and in everything. A human being is both energy and matter. Angels make reference to a transcendent reality.

Inscriptions are also icons. They have the same importance with the image, they have a complementary role. A similar problem is addressed by Michael Foucault in his analysis of the painting called "The Treachery of Images" (Ceci n'est pas une pipe) by Rene Magritte in 1929. Here Foucault examined the relationship between word and image which represents striking resemblances to the Byzantine theory and practice of representing angels. Here the inscription contradicts the mimetic character of the image. We are talking about a representation of a material symbol that the viewer cannot interpret in the literal sense. After contemplating the icon, the viewer fully realizes that "This is not an angel."

The Holy Bible teaches that angels were created by God before the 
creation of the material world. God created them in very large numbers, myriads of angels, according to the tradition of Church, which means an enormous number.

Scripture tells us that before the creation of the material world, a crucial event took place in the spiritual world of angels throughout history: one of the angels, Lucifer, who took part in the Cherubim Order according to some traditions, rebelled against God, dragging in his fall other angels, from the other holy orders.

We are told that Lucifer was one of the most beautiful angels created by God. Becoming aware of this, Lucifer, who calls himself " the bearer of light," imagined that he could become God himself, considering himself equal to his Creator.

The moment of this thought caused his fall from the glory of God, because he didn't understand that God is the One who is the source of his existence and beauty. Falling into this thought of pride, Lucifer lost the light that God gave him, remaining in a completely existential darkness.

Even though the abilities of these angels like: speed, power and immortality remained active, their minds, devoid of the light of divine grace, darkened, rendering these angels incapable of perceiving good, which is why they became so engrossed in a fierce hatred against God, against His creation and against people.

The number of fallen angels was quite large, being part of all angel hierarchies. As the Holy Bible tells us their fall was stopped by Archangel Michael's attitude, who said: "Let us attend! Let us stand aright! Let us stand with fear!"

The fallen angels', demons' and devils' hatred against people, as they are called in the Scriptures, denoting the cunning and breaking of God, caused a fall of people through the famous episode of Eve's and Adam's fall into sin at the serpent's temptation.

Christian theology says that fallen angels' envy and wickedness influenced the fate of mankind, in the sense of the world as we know nowadays, a world in which through the cunning of the fallen angel sin entered, and through sin death entered the world.

We can only imagine how world would have looked like if Adam's and Eve's sin hadn't existed, as from scriptural accounts we find out that God created a good world in the beginning and the human being was invested with the power of immortality (which was different from angels' immortality; he only had the power of being immortal if he obeys God's will).

Dionysius researched various passages of Scripture that mention angels epiphanies in search of patterns. In his work called "Heavenly Hierarchy," he examined in detail God's unincorporated creatures. In this book he formulates a point of view regarding the images of angels (by creating a connection between verbal and visual symbolism, pp. 131-132). 
He also states that angels can take different forms, for example: the shape of a lion to express its power, or they are represented with the appearance of a bull to symbolize knowledge; they can have the appearance of an eagle to symbolize freedom in the light of God; the appearance of a horse was assumed due to obedience which is a specific attribute to angels. According to Dionysius, symbols are the main way to know God, but the most common appearance of an angel is the human one (a human being is also used as a symbol). The anthropomorphism of angels as a visual representation is based on the power of understanding the human mind. Artistic depictions of angels are considered to be visual symbols. These disembodied beings have been seen in time and space in certain circumstances. St. John of Damascus wrote: "They are circumscribed. Because when they are in heaven they are not on earth, and when they are sent by God on earth they are not in heaven anymore" (p. 151). God created them in his own image, an intangible nature, a kind of immaterial spirit and fire, as St. John of Damascus states. Thus, angels are spiritual beings in constant motion, having free will, they are intangible and immaterial, but only in relation to us humans, because in relation to God, who is incomparable, they are inferior ". These beings can be circumscribed in space just like the soul is located in body and just like demons whose creature is similar to that of angels. God Himself is intangible, omnipresent, and his presence permeates all creation (we find these statements in the book "Intangible Bodies" at page no. 154). Holy Scripture is quoted as the primary source of inspiration, where God commands Moses to build the Ark of the Law (Exodus 25:22).

"There, above the cover between the two cherubim that are over the ark of the covenant law, I will meet with you and give you all my commands for the Israelites". So the cherubim are directly mentioned by God in His commandments for building the Ark of the Law. (Exodus 25.18-20) and it's the most important invoked example in which God explicitly requires the production of figurative images. The cherubim above the ark have become an argument of the utmost importance for representations based on this scriptural precedent. Cherubim occupy a high position in the celestial hierarchy. They are the closest to God. They can be perceived by the eyes of our mind as a form - matter. According to St. John of Damascus, angels are represented with wings because such images are easier to apprehend by the lower power of the human mind. Human understanding can approach icon on a spiritual level. "The appearance of angels are symbolic manifestations, perceived on a spiritual level." Similarly, the representations of angels must be considered as symbols addressed to intellect and not to sight. (p. 163). Patriarch Nichifor described the icons of angels as a means of Divine knowledge by contemplating and meditating on their unseen and ineffable appearance. (p. 164). In Byzantine painting the image of angels is accompanied by text (the inscriptions bear the names of angels, both the 
anthropomorphic image and the inscriptions are icons with a complementary role). Winged young men, accompanied by their name, is the most common representation (these images are simple symbols for the enigmatic representation of angels. Page 172). The one who contemplates the icon of an angel is captivated by the material object made with the help of colors and shapes, and based on these aspects he fully realizes that "he is not an angel" (p. 173). Andrei Pleșu remarks in the book "About Angels" that this theme ("The Theme of Angels") is interesting both from a theological and philosophical and existential point of view. We can add to Andrei Pleşu's statement another field of research from which this topic about angels representation can be thoroughly studied, namely: art. Art, since ancient times, has symbolically represented both the winged human being and other winged beings that may suggest the existence of angels. The area of angels manifestation is the space between earth and sky, being perceived as rising and falling energies. All writings reveal us that the space between the Supreme Being and the earthly world is very crowded.

Time, space and matter are the three dimensions of existence which, considered as iconic essential elements, can be represented from the perspective of visual language elements in an experimental, dynamic vision, that is in a constant transfiguration process, by using personal solutions in the attempt to transmit the intended meaning.

The sacred, this inexhaustible source of inspiration, is also for visual arts an action field of of contemporary creative manifestations. The need to open new perspectives, new interpretive ways wihin a contemporary spiritual vision of the conceptual sacred sphere includes a broad direction.

The essential forms of sacred manifestation refer to the metaphysical image specific to a philosophical or personified religious vision of such a complex concept.

Understanding the meanings and the depths assimilated from the perspective of symbol, the anonymous artist's ancient gesture refers to the fundamental values, to a reflection on the relationship between ephemeral and perennial. Here we have the border between archaic and modern, where the comparison of systems made possible their understanding and transformation into a visual approach.

In the artistic space, the role of (Divine) inspiration within the creative process is essential and becomes a mandatory condition.

Thus conceived, the present study, which is the object of debate about Angels from an artistic perspective, has as main interest the investigation of their world from the point of view of their visual representation.

Taking into account the various points of view regarding the notion of the sacred, we can debate this problem from the perspective of personal artistic solutions. In artistic creation, a subjective vision is neccesary for the 
spiritual issue. We hope that in the near future sacred art will find its rightful place among visual creations, both by the importance of the theme and by the complexity and richness of expressed values and will also be able to offer life-saving solutions to the growing needs of the current era.

The thematic nucleus from which I started, trying to search for the spiritual in order to find myself, is complex and has a symbolic and artistic content. Specific visual expressions have a great ability for revelation and convey to viewer the idea of meaning as if he would create special energies, influencing the feeling of a real discovery.

The sacred still imposes on artists ways in which thinking and feeling can be channeled into high quality creations.

The sacred can be a source of inspiration in one's own representations through re-evaluations, reinterpretations or rediscoveries for a spiritual continuity, an ancestral conception of world and life strongly based on the laws of a spiritual nature.

Approaching painting from the perspective of ways of representing symbols, in the context of contemporary visual arts, deepens their importance and opens perspectives for new interpretations.

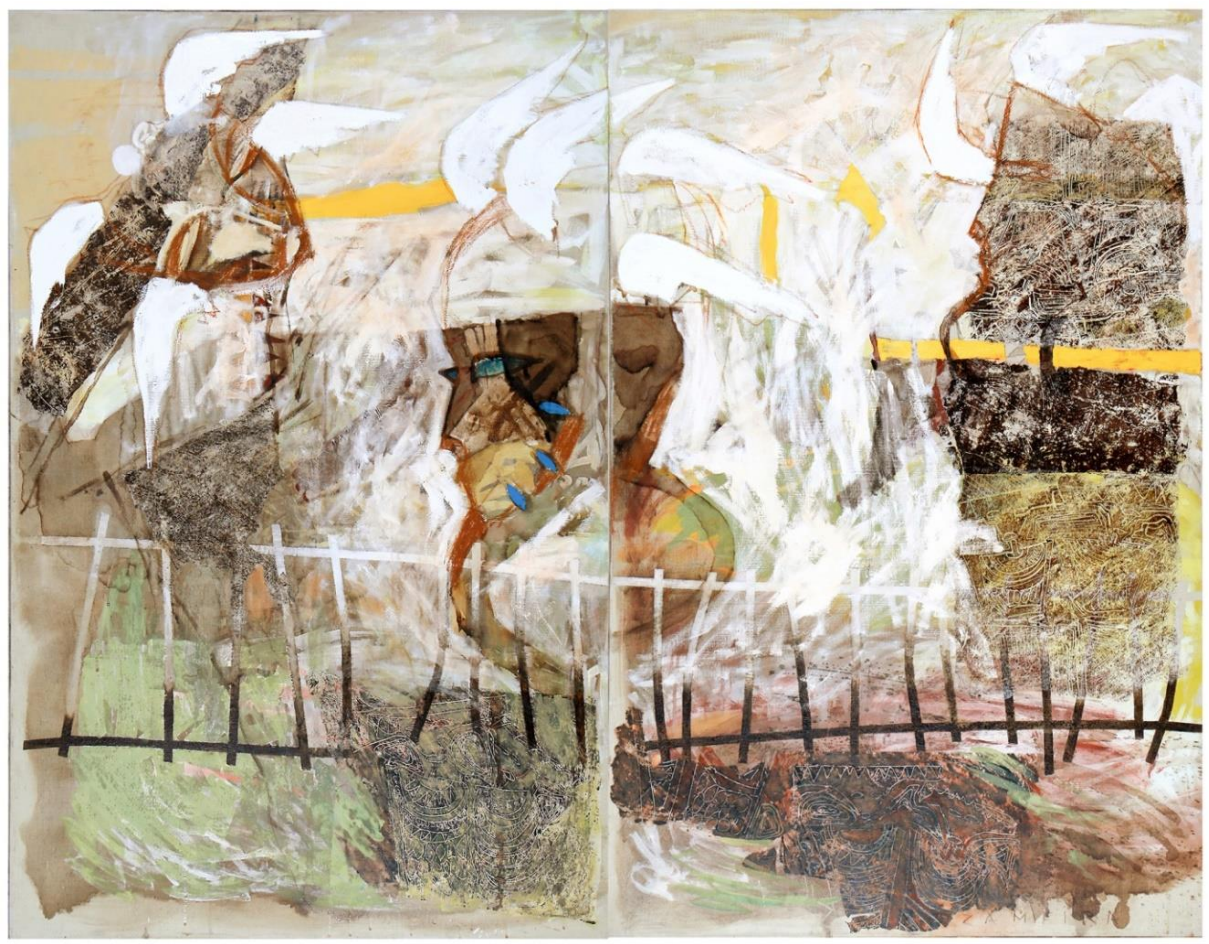

Fig. 1. Zamfira Bîrzu, "Seraphim", 120/160 cm, m. t./canvas 


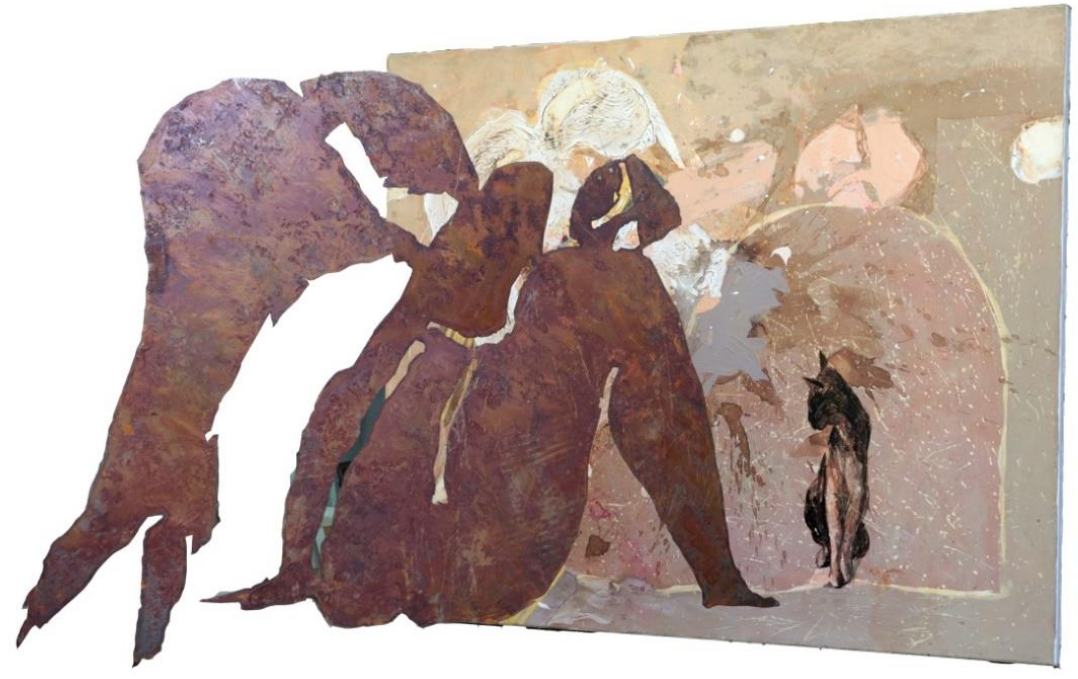

Fig. 2. Zamfira Bîrzu, "Angel", mixed technique, painting/canvas in the background $100 / 120 \mathrm{~cm}$, metal in the foreground $100 / 100 \mathrm{~cm}$.

\section{Bibliography:}

Pleșu, Andrei, Despre îngeri, Humanitas, Bucharest, $2^{\text {nd }}$ edition, 2008.

Dionisie Areopagitul, Ierarhia cerească. Ierarhia bisericească , Institutul European Publishing House, Iași, 1994.

Maica Alexandra, Sfinții îngeri, Anastasia Publishing House, Bucharest, 2002.

Glenn Peers, Trupuri Imateriale, Nemira Publishing House, Bucharest, 2011. 